\title{
Modyfikacja warstwy wierzchniej biomateriałów na przykładzie tytanu metodą stopowania plazmowego
}

\author{
Biomaterials surface modification \\ on the titanium example by microplasma alloying
}

\section{Streszczenie}

W artykule przedstawiono wyniki modyfikacji warstwy wierzchniej tytanu metodą stopowania plazmowego powierzchni, a następnie jej trawienia elektrochemicznego. Zastosowanie prekursora nanokrystalicznego w istotny sposób wpływa na właściwości wyjściowe otrzymywanych warstw. Zastosowanie procesu mechanicznej syntezy prowadzi do zmniejszenia wielkości ziarna prekursora z jego częściową amorfizacją. Zmodyfikowaną przez proces stopowania plazmowego mikrostrukturę obserwowano przy użyciu mikroskopii optycznej. Dla zastosowanego nanoprekursora proszkowego otrzymano strukturę kompozytową warstwy składającą się z matrycy $\mathrm{Ti}(\alpha)$ oraz wydzieleń fazy TiB potwierdzoną badaniami strukturalnymi XRD. Uzyskano znaczący wzrost mikrotwardości otrzymanej warstwy $900 \mathrm{HV}$ w porównaniu z podłożem $160 \mathrm{HV}$. Zaprezentowano wyniki badań biokompatybilności otrzymanej warstwy na hodowli komórkowej ludzkich osteoblastów w zestawieniu z mikrokrystalicznym tytanem. Wykonano testy odporności korozyjnej w roztworze Ringera w temperaturze $37^{\circ} \mathrm{C}$, powierzchni po modyfikacji. $Z$ analiz wynika, iż stopowanie plazmowe jest efektywną metodą wytwarzania warstw kompozytowych typu Ti+TiB.

\section{Wstęp}

Tytan i jego stopy wyróżnia wiele unikatowych właściwości, do których zaliczyć można wysoką wytrzymałość zmęczeniową nawet w podwyższonej temperaturze,

Mgr inż. Andrzej Miklaszewski, prof. dr hab. inż. Mieczysław Jurczyk - Politechnika Poznańska, dr Mieczysława Jurczyk - Uniwersytet Medyczny, Poznań. jak również wysoką wytrzymałość właściwą. Cechy te zostały docenione i są szeroko wykorzystywane w przemyśle chemicznym, petrochemicznym, lotniczym czy też kosmicznym, materiały te wypierają również z niektórych obszarów stopy konwencjonalne. Wysoka odporność korozyjna, które tytan zawdzięcza pasywacyjnej warstwie tlenkowej oraz niski moduł sprężystości przede wszystkim w odniesieniu do nowoczesnych stopów beta wraz z wysoką biokompatybilnością czynią go najszerzej stosowanym materiałem implantacyjnym [1]. Do najpoważniejszych wad tytanu i jego 
stopów zaliczyć należy jego niską odporność na ścieranie, wynikającą z nieznacznej twardości oraz łatwości łuszczenia i zacierania współpracujących węzłów tarciowych. Zagadnienia te, szczególnie istotne pod kątem zastosowań medycznych, były i są tematem wielu prac badawczych. Podwyższenie odporności na zużycie przez modyfikację powierzchniową, wytwarzanie powłok lub objętościowe wytwarzanie kompozytów czy też materiałów gradientowych ma na celu zmniejszenie intensywności lub eliminację niekorzystnych zjawisk tym samym poprawę warunków i komfortu życia [2]. Środowisko organizmu ludzkiego, w przypadku którego zmiennymi czynnikami są zarówno temperatura, jak i odczyn pH $(3,5 \div 9)$ sprawiają trudności w projektowania materiałów implantacyjnych. Zachodzące procesy powierzchniowe wymiany ładunków, adsorpcji czy reakcji komórkowych oraz rządzącu nimi mechanizmy są trudnymi i złożonymi zagadnieniami, do tej pory nie w pełni poznanymi. Powodzenie procesu osteointegracji według prowadzonych obecnie badań zależne jest od wielu czynników powierzchniowych. Dowodzi się iż chropowatość wpływa na morfologię oraz wzrost komórkowy, topografia natomiast przez zagłębienia i wzniesienia może działać na jego kierunek i przyczepność kolonii [3]. Nie bez znaczenia pozostaje również chemiczno-fizyczny stan powierzchni definiujący energię powierzchniową, której wartość może ulegać zmianom w wyniku zachodzących interakcji komórkowych.

Obecne starania zmierzające do poprawy właściwości tytanu i jego stopów jako materiałów implantacyjnych realizowane są różnymi metodami modyfikacji, zarówno metod objętościowego umacniania przez otrzymywanie kompozytów [4], jak również ingerencję w warstwę wierzchnią lub wytwarzanie powłok. Szeroko rozpowszechniona metoda natryskiwania warstw, możliwa do realizacji w kontrolowanej atmosferze, pozwala uzyskiwać oczekiwane efekty również w kontekście zastosowań medycznych. Szczególnie znaczącym pozostaje fakt uzyskiwania wysokiej biokompatybilności, co udaje się osiągnąć wraz z podwyższeniem właściwości użytkowych w przypadku $\mathrm{ZrO}_{2}, \mathrm{Al}_{2} \mathrm{O}_{3}$ pokryć wollastonitowych czy też hydroksyapatytowych

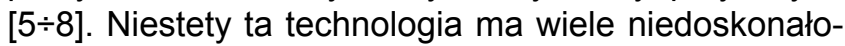
ści, do których należy zaliczyć słabą przyczepność powłok oraz w niektórych przypadkach ich niską krystaliczność, co może być bezpośrednią przyczyną ich rozpuszczania w kontakcie ze środowiskiem płynów ustrojowych [9]. Występowanie niekorzystnych zjawisk delaminacji lub skrócenia czasu użytkowania przez rozpuszczanie, w przypadku aplikacji medycznych wiąże się z koniecznością powtórnego zabiegu zwiększającego jednocześnie ryzyko powikłań.

Najczęściej rozwiązaniem modyfikacji warstwy wierzchniej tytanu i jego stopów celem poprawy właściwości użytkowych jest obróbka termo- lub elektrochemiczna. Borowanie, nawęglanie, azotowanie, czy tez najszerzej stosowane utlenianie powierzchniowe może być realizowane w zależności od zastosowanej metody lub kilku z nich naraz (w przypadku obróbki hybrydowej) na określoną głębokość. Umocnienie roztworowe jak również zamierzone wytwarzanie twardych faz oraz możliwe zastosowanie obróbki elektrochemicznego trawienia celem rozwinięcia powierzchni daje szerokie spektrum aplikacyjne. Szczególnie istotna jest możliwość jednoczesnego utleniania materiału na określoną głębokość, jak również regulacja parametrów chropowatości oraz topografii, które w istotny sposób wpływają na powodzenie procesów osteointegracji przez zmiany energii powierzchniowej czy też kąta zwilżania.

Metody obróbki skoncentrowanymi źródłami energii stanowiące przyszłość obecnych wyzwań inżynieryjnych, pozwalają na szybkie przechłodzenie struktury, skutkując wysokim wzrostem właściwości mechanicznych. Silne skupienie wiązki oraz jej duża moc wraz ze znacznym gradientem temperaturowym pozwalają na wykonywanie procesów cięcia i spawania oraz modyfikowania powierzchniowego materiałów również w podejściu hybrydowym. Laserowe napawanie, przetapianie czy stopowanie znajduje coraz szersze ob-

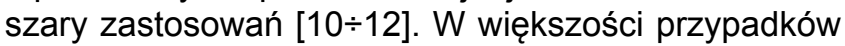
otrzymywane warstwy wykazują ostre przejście właściwości od powierzchni w kierunku podłoża, czasem również zauważalny jest brak odpowiedniego połączenia metalurgicznego. Taka sytuacja jest niekorzystna, ponieważ może być przyczyną pękania lub delaminacji warstw ze względu na występujące duże zmiany rozkładu naprężeń mikrostruktury i powinno się jej unikać w celu wydłużenia użytkowania.

Zastosowana w pracy metoda modyfikacji powierzchni przy użyciu stopowania plazmowego daje możliwość wytwarzania kompozytowych warstw $\mathrm{Ti}+\mathrm{TiB}$ o polepszonych względem podłoża właściwościach. Pozwala również na zachowanie właściwego połączenia metalurgicznego wraz z gładkim przejściem właściwości od podłoża w kierunku warstwy. Modyfikacja elektrochemiczna wytworzonej warstwy, której celem jest zwiększenie powierzchni właściwej, wpływa korzystnie na wzrost i przyczepność hodowli komórkowej. Celowe zastosowanie w procesie stopowania prekursorów proszkowych wytworzonych przy użyciu metody mechanicznej syntezy (MA - mechanical alloying) oraz odpowiednia kontrola parametrów procesu wpływa na właściwości końcowe warstwy omówione w części wynikowej.

\section{Materiały i metoda}

Celem wytworzenia kompozytowej powłoki Ti+TiB o unikatowych właściwościach zastosowano proces stopowania plazmowego, polegający na przetopieniu wcześniej naniesionego na podłoże materiału prekursora proszkowego w postaci mieszaniny z rozcieńczonym szkłem wodnym. Istotne dla procesu otrzymywania oczekiwanej warstwy są zarówno parametry procesu, do których należy zaliczyć rodzaje i natężenia przepływu gazów plazmowego, osłonowego oraz dodatkowego, 
jak i parametry mocy, prędkości stopowania, średnice dyszy plazmowej oraz jej odległości od materiału. Powstająca mikrostruktura zależy również od składu chemicznego, ilości oraz charakteru materiału prekursora (nano/mikro). Nanoprekursor proszkowy z dodatkiem $10 \%$ wag. B został przygotowany z materiałów wyjściowych Alfa Aesar $(<45 \mu \mathrm{m})$ boru i tytanu o czystości odpowiednio 98\% i 99\% przy użyciu procesu mechanicznej syntezy. Nanoprekursor otrzymano w wyniku 48 h syntezy w atmosferze ochronnej Ar, analizując otrzymane struktury przy użyciu metody rentgenowskiej XRD, wypromieniowaniem charakterystycznym Cu Ka1. Po procesie określono metodą Sherrera średnią wielkość ziarna. Celem przygotowania materiał podłoża ( $\mathrm{Ti}$ - grade 2) został zeszlifowany papierem o gradacji 1000 a następnie płukany w acetonie, alkoholu i wodzie destylowanej przy użyciu myjki ultradźwiękowej. Na tak przygotowaną i osuszoną powierzchnię nałożono w formie ścieżki mieszaninę prekursora ze szkłem wodnym i pozostawiono do wyschnięcia.

Proces spawania plazmowego zmodyfikowano na wzór metody stopowania laserowego, przetopienia dokonywano skoncentrowanym łukiem plazmowym o stałych parametrach. Szerokość ścieżki stopowania uzależniono od parametrów procesu, tj. średnicy dyszy plazmowej jej odległości od materiału modyfikowanego oraz wstępnie przygotowanej ścieżki napawania. Modyfikacja powierzchni w rozważanym podejściu jest realizowana przez przetopienie materiału nałożonego wcześniej, utworzenie warstwy o odmiennym składzie chemicznym i podwyższonych względem podłoża parametrach mechanicznych oraz silnego połączenia metalurgicznego w obszarze międzywarstwy. Modyfikacja warstwy wierzchniej jest realizowana w procesie trawienia elektrochemicznego i polega na zwiększeniu jej powierzchni właściwej, celem poprawy parametrów adhezji komórkowej.

W wyniku przetopienia określonej ilości wagowej materiału prekursora proszkowego dla zdefiniowanej powierzchni, przy określonych parametrach procesu dochodzi do powstania jednorodnej warstwy. Do wytworzenia warstwy kompozytowej użyto urządzenia Microplasma EWM50 z palnikiem PHB50 wyposażonym w dodatkowy nadmuch od strony lica oraz płytę chłodzącą w układzie otwartym wody. Stopowania dokonywano przy stałych nastawach wysięgnikiem spawalniczym o regulowanej prędkości ruchu zgodnie $z$ opisem znajdującym się w [13]. Modyfikacji warstwy wierzchniej dokonano przy użyciu metody trawienia elektrochemicznego w 0,1 mol. $\mathrm{H}_{3} \mathrm{PO}_{4}+2 \% \mathrm{HF}$ przez $1 \mathrm{~h}$ dla stałej wartości potencjału $10 \mathrm{~V}$. Skład fazowy otrzymywanych warstw był analizowany metodą rentgenowską XRD promieniowaniem charakterystycznym $\mathrm{Cu} \mathrm{Ka}_{1}$. Dokonano obserwacji powstałej mikrostruktury przy użyciu metod optycznych, wyznaczono średnią twardość warstw, stosując metodę Vickersa przy obciążeniu $300 \mathrm{~g} \mathrm{w}$ czasie $10 \mathrm{~s}$, oraz zbadano odporność korozyjną w próbie potencjodynamicznej w roztworze
Ringera w temperaturze $37^{\circ} \mathrm{C}$ dla zakresu potencjału $-1 \div 1 \mathrm{~V}$ przy kroku $1 \mathrm{mV} / \mathrm{s}$. Profil topografii powierzchni został odwzorowany za pomocą profilometru optycznego Veeco Wyko@ NT1100. Testy in vitro biokompatybilności przeprowadzono w warunkach statycznych. Dla celów porównawczych zestawiono próbkę otrzymana w wyniku stopowania plazmowego nano prekursorem z 10\% wag. dodatkiem B wraz z następnie trawioną elektrochemicznie powierzchnią oraz tytanem mikrokrystalicznym. Próbki poddano sterylizacji w temperaturze $120^{\circ} \mathrm{C}$ przez 15 minut i umieszczono oddzielnie na dnie wypustek specjalnej płytki dodając do każdej hodowlę ludzkich komórek osteoblastów firmy Lonza w koncentracji 5000 komórek na próbkę w 1 ml medium hodowlanego. Celem rozwoju hodowli komórki poddano inkubacji w temperaturze $37^{\circ} \mathrm{C}$ i atmosferze o $5 \%$ zawartości $\mathrm{CO}_{2}$ przez 1 dzień. Następnie hodowlę utrwalono $25 \%$ roztworem glutaraldehydu przez 10 min i zabarwiono 10\% roztworem barwnika Giemsy również przez 10 min. W celu umożliwienia obserwacji na skaningowym mikroskopie elektronowym próbki pokryto warstwą złota.

\section{Wyniki badań}

Nanoprekursor proszkowy otrzymany w wyniku 48 h syntezy poddano analizie wielkości ziarna metodą Sherrera i określono jej próg w granicach $10 \div 20 \mathrm{~nm}$. Analiza XRD materiału po MA wykazała tendencję w kierunku amorfizacji o czym świadczy wyraźne zmniejszenie intensywności pojawiających się refleksów od płaszczyznowych wraz z ich znacznym poszerzeniem (rys. 1a).

Wynikiem takiego zachowania analizowanego materiału jest generowanie podczas procesu znacznej ilości dyslokacji oraz innych defektów sieciowych których źródłem są periodycznie powtarzające się zderzenia mielników z uwięzionymi pomiędzy nimi cząstkami, wywołujące silne odkształcenia. Długotrwałe

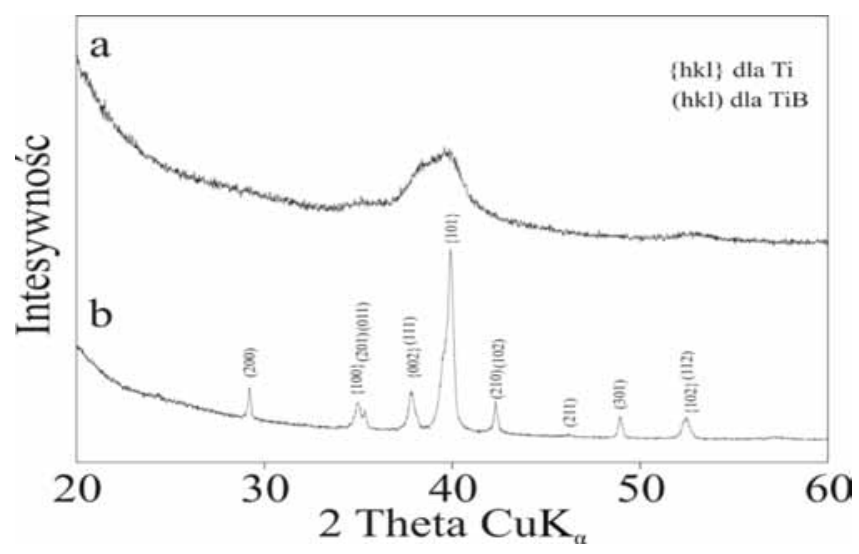

Rys. 1. Analiza strukturalna XRD: a) otrzymanego po 48 h syntezy prekursora z $10 \%$ wag. dodatkiem $B$, b) warstwa uzyskana w wyniku stopowania plazmowego prekursora nano z $10 \%$ wag. dodatkiem $B$. Fig. 1. XRD spectra of: a) precursor powder with 10 wt. $\%$ B after $48 \mathrm{~h} \mathrm{MA}, \mathrm{b})$ plasma alloyed surface with $10 \mathrm{wt}$ \% $\mathrm{B}$ 

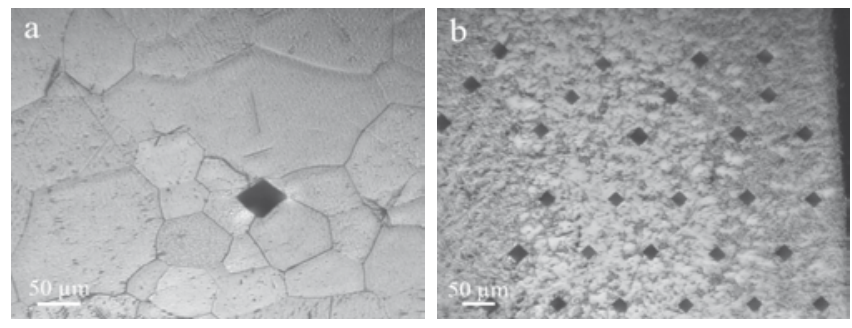

Rys. 2. Mikrostruktura: a) czystego tytanu, b) powłoki otrzymanej w wyniku stopowania plazmowego $z$ zastosowanym nano prekursorem z 10\% wag. dodatkiem $B$

Fig. 2. Microstructure of: a) pure titanium, b) obtained after microplasma alloying layer with 10 wt. \% B
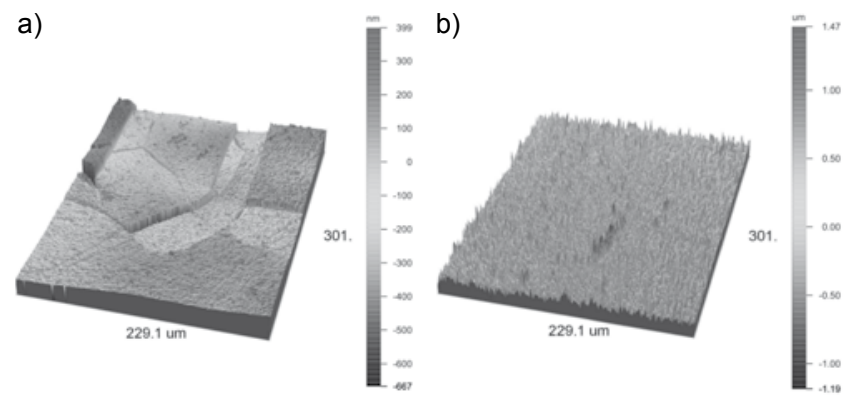

c)

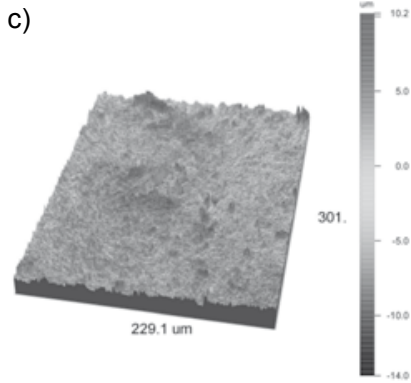

Rys. 3. Profile topografii powierzchni dla: a) tytanu mikrokrystalicznego, b) warstwy stopowanej plazmowo, c) po modyfikacji elektrochemicznej

Fig. 3. Surface topography profiles of: a) microcrystalline titanium, b) plasma alloyed layer, c) layer after electrochemical modification
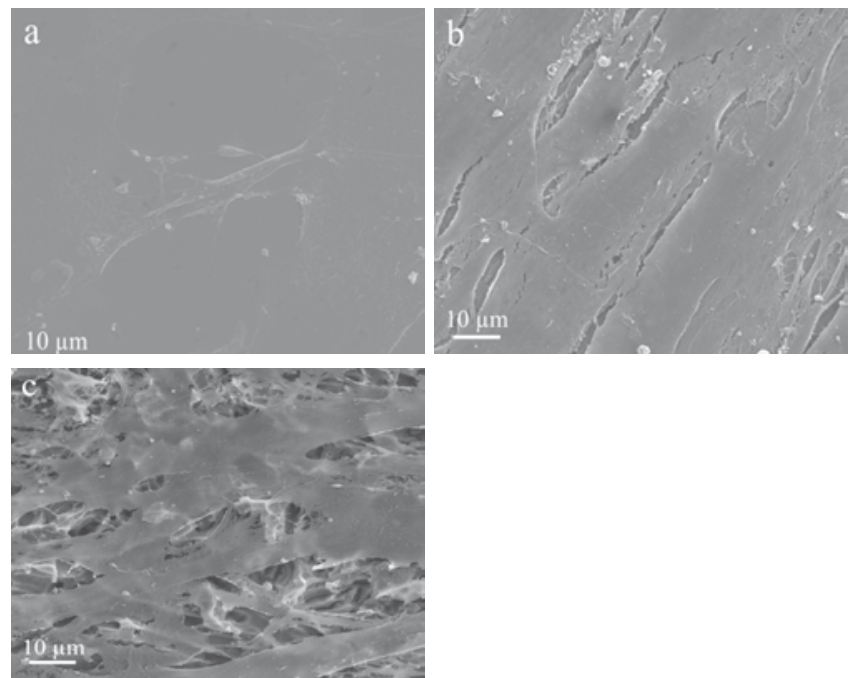

Rys. 4. Obraz ze skaningowego mikroskopu elektronowego hodowli komórkowej osteoblastów po 24 h: a) na powierzchni podłoża - tytan mikrokrystaliczny b) na warstwie wytworzonej w wyniku stopowania plazmowego przy użyciu nanoprekursora z 10\% wag, c) dodatkiem B warstwa po modyfikacji elektrochemicznej

Fig. 4. Scanning electron micrographs after $24 \mathrm{~h}$ of osteoblast cultured on: a) substrate material - microcrystalline titanium, b) obtained after plasma alloying layer with 10 wt. \% B, c) layer after electrochemical modification mielenie materiału powoduje pękanie i kruszenie łączonych wcześniej cząstek, prowadząc do zmniejszenia wielkości części składowych mieszaniny i odsłaniając czyste powierzchnie w skali atomowej. Zastosowane podejście pozwala nie tylko na zmniejszenie wielkości ziarna prekursora proszkowego, ale zapewnia również równomierne rozłożenie w matrycy materiału dodatku. Analiza strukturalna powłoki (rys. 1b) wskazuje na wyraźny udział fazy matrycy $\mathrm{Ti}(\alpha)$ oraz wydzieleń TiB, odpowiedzialnych za wzrost twardości. Użyty nanoprekursor proszkowy jest odpowiedzialny za szybsze zarodkowanie fazy umacniającej TiB oraz jej dyspersję.

Wzrost parametrów użytkowych biomateriałów wynikający z literatury wskazuje na właściwy kierunek podjętych zabiegów modyfikacji. Zastosowane podejście umożliwia uzyskanie wypadkowej twardości warstwy na poziomie $870 \mathrm{HV}$ (rys. 2b), podczas gdy twardość czystego tytanu mikrokrystalicznego - materiału podłoża, wynosi zaledwie 160 HV (rys. 2a). Podwyższenie właściwości mechanicznych, jak również odpowiednia kontrola parametrów powierzchniowych, możliwa do realizacji w procesie trawienia elektrochemicznego, warunkuje odpowiedni rozwój hodowli komórkowej, zwiększając jednocześnie jej przyczepność, co zostało potwierdzone zestawieniem badań topografii powierzchni (rys. 3) z badaniami hodowli komórkowej (rys. 4).

W celu określenia biozgodności wytworzonej przy użyciu metody stopowania plazmowego warstwy z nanoprekursorem zastosowano badania in vitro. Metoda ta pozwala na określenie toksyczności materiałów poprzez analizę możliwość rozwoju hodowli lub jej braku na badanej powierzchni. $Z$ rysunku 4 wynika, iż zastawiona hodowla komórkowa osteoblastów wykazuje prawidłowy kierunek wzrostu na badanej powierzchni. Porównanie warstwy wytworzonej przy użyciu metody stopowania plazmowego z nanoprekursora z 10\% wag. dodatkiem boru

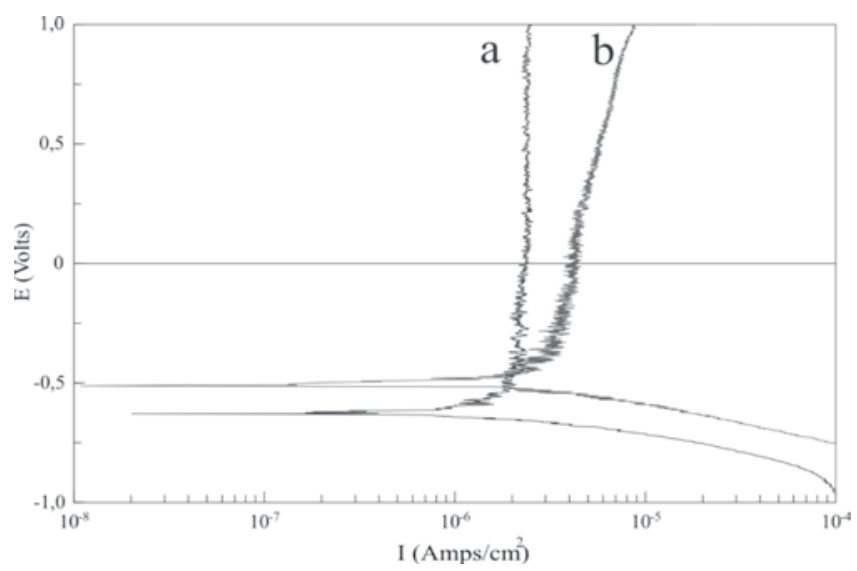

Rys. 5. Badania odporności korozyjnej przy użyciu krzywych potenjcodynamicznych w roztworze Ringera $w$ temperaturze $37^{\circ} \mathrm{C}$ dla: a) materiału podłoża - tytan mikrokrystaliczny, b) warstwy wytworzonej przy użyciu prekursora nano z $10 \%$ wag. dodatkiem B

Fig. 5. Surface corrosion resistance potentiodynamic curves of: a) substrate material - microcrystalline titanium, b) layer obtained after plasma alloying with 10 wt.\% B in Ringer solution at $37^{\circ} \mathrm{C}$ 
z mikrokrystalicznym tytanem dostarcza również informacji o wyraźnie silniejszej tendencji rozwoju koIonii. Prawidłowe narastanie komórek wynikające z ich namnażania oraz całkowite pokrycie badanej powierzchni dostarcza informacji o biozgodności wytworzonych warstw. W przypadku elektrochemicznej modyfikacji warstwy wierzchniej można zaobserwować zauważalny wpływ topografii na zdolność zakotwiczania hodowli. W przypadku mikrochropowatości, zgod- nie z literatura, następuje polepszenie przyczepności, jak również widoczny jest korzystny wpływ na adhezję komórkową oraz zdolności proliferacji.

Wykonane badania odporności korozyjnej w próbie potencjodynamicznej w roztworze Ringera w temperaturze $37^{\circ} \mathrm{C}$ wskazują, iż otrzymane wartości prądu korozyjnego są zbliżone do tytanu mikrokrystalicznego (rys. 5).

\section{Wnioski}

W zaproponowanym podejściu wytworzono przy użyciu metody stopowania plazmowego warstwę kompozytową Ti+TiB o podwyższonych parametrach użytkowych. Następnie celem rozwinięcia powierzchni i poprawy zdolności adhezji komórkowej poddano ją trawieniu elektrochemicznemu. Dokonano odwzorowania profilu topografii powierzchni uzyskanych w wyniku tych zabiegów, ukazując je w zestawieniu z obrazami hodowli komórkowej ze skaningowego mikroskopu elektronowego. Zastawiona hodowla komórkowa ludzkich osteoblastów wykazuje tendencję prawidłowej kolonizacji powierzchni badanych, świadcząc o wysokiej biozgodność charakteryzowanych warstw uzyskanych metodę stopowania plazmowego. Badania odporności korozyjnej w roztworze Ringera w temperaturze $37^{\circ} \mathrm{C}$ wskazują na zachowanie charakteru materiału mimo struktury dwufazowej.

\section{Literatura}

[1] R.R. Boyer: An overview on the use of titanium in the aerospace industry, Materials Science and Engineering A 213 (1996) 103.

[2] K.B. Panda, K.S. Ravi Chandran: Titanium-Titanium Boride (Ti-TiB) Functionally Graded Materials through Reaction Sintering: Synthesis, Microstructure, and Properties, Metallurgical and Materials Transactions 34A (2003) 1371.

[3] Marc Long, H.J. Rack: Titanium alloys in total joint replacement - a materials science perspective. Biomaterials 19 (1998) 1621.

[4] K.B. Panda, K.S. Ravi Chandran: Synthesis of Ductile Titanium-Titanium Boride (Ti-TiB) Composites with a Beta-Titanium Matrix: The Nature of TiB Formation and Composite Properties, Metallurgical and Materials Transactions 34A (2003) 1993.

[5] R. Gadow, A. Killinger, N. Stiegler : Hydroxyapatite coatings for biomedical applications deposited by different thermal spray techniques, Surface \& Coatings Technology 205 (2010) 1157.

[6] Giovanni Bolelli, Valeria Cannillo, Rainer Gadow, Andreas Killinger, Luca Lusvarghi, Antonella Sola, Nico Stiegler "Microstructure and in-vitro behaviour of a novel High Velocity Suspension Flame Sprayed (HVSFS) bioactive glass coating, Surface \& Coatings Technology 205 (2010) 1145

[7] Guocheng Wang, Fanhao Meng, Chuanxian Ding, Paul K. Chu, Xuanyong Liu, Microstructure, bioactivity and osteoblast behavior of monoclinic zirconia coating with nanostructured surface. Acta Biomaterialia 6 (2010) 990.
[8] Guocheng Wang, Fanhao Meng, Chuanxian Ding, Paul K. Chu, Xuanyong Liu: Microstructure, bioactivity and osteoblast behavior of monoclinic zirconia coating with nanostructured surface, Acta Biomaterialia 6 (2010) 990.

[9] Xuanyong Liu, Ray W.Y. Poon, Sunny C.H. Kwok, Paul K. Chu, Chuanxian Ding: Plasma surface modification of titanium for hard tissue replacements, Surface \& Coatings Technology 186 (2004) 227.

[10] Manoj Masanta, P. Ganesh, Rakesh Kaul, A.K. Nath, A. Roy Choudhury: Development of a hard nano-structured multi-component ceramic coating by laser cladding, Materials Science and Engineering A 508 (2009) 134.

[11] Yuling Yang, Duo Zhang, Wei Yan, Yiran Zheng: Microstructure and wear properties of TiCN/Ti coatings on titanium alloy by laser cladding, Optics and Lasers in Engineering 48 (2010) 119.

[12] M. Alhammad, S. Esmaeili, E. Toyserkani: Surface modification of Ti-6Al-4V alloy using laser-assisted deposition of a Ti-Si compound, Surface \& Coatings Technology 203 (2008) 1.

[13] A. Miklaszewski, M.U. Jurczyk, K. Jurczyk, M. Jurczyk: Plasma surface modification of titanium by TiB precipitation for biomedical applications, Surface and Coatings Technology (SCT_16891) - accepted

Materiały dotyczące Wielkopolski pomogli zebrać oprócz wymienionych: mgr inż. Buchowski Jacek, mgr inż. Czeladziński Łukasz, Nowak Marcin, mgr inż.Nowak Tomasz, mgr inż. Wiśniewski Daniel (IWE), Wiśniewski Michał 